Meta

Journal des traducteurs

Translators' Journal

\title{
Towards the Understanding of Translation in Psychoanalysis
}

\section{Patrick Mahony}

Volume 27, numéro 1, mars 1982

Psychanalyse et traduction

URI : https://id.erudit.org/iderudit/003537ar

DOI : https://doi.org/10.7202/003537ar

Aller au sommaire du numéro

Éditeur(s)

Les Presses de l'Université de Montréal

ISSN

0026-0452 (imprimé)

1492-1421 (numérique)

Découvrir la revue

Citer cet article

Mahony, P. (1982). Towards the Understanding of Translation in Psychoanalysis. Meta, 27(1), 63-71. https://doi.org/10.7202/003537ar d'utilisation que vous pouvez consulter en ligne.

https://apropos.erudit.org/fr/usagers/politique-dutilisation/ 


\section{TOWARDS \\ THE UNDERSTANDING \\ OF TRANSLATION \\ IN PSYCHOANALYSIS}

Patrick Mahony

The concept of translation had a central importance in Freud's writings, an importance unfortunately neglected in subsequent psychoanalytical commentary. Because of its widespread and multi-leveled meanings, translation is truly a theoretical nodal word, or, in the terminology of modern physics, a unified field concept which illustrates the interaction of intrasystemic, intersystemic and interpsychic phenomena. A thorough understanding of the concept of translation will enable the analyst to appreciate a new coherence in Freud's works as well as to acknowledge Freud's historical eminence as one of the great thinkers and innovators in the domain of translation. Freud ought rightly to be ranked as one of the major theoreticians of translation for he gives the concept a scope, extension and depth in his work that appeared nowhere previously in history. It is, therefore all the more curious that the recent attempts in various languages to relate psychoanalysis and semiotics or the study of signs have not rendered justice to the centrality of translation (Liberman; Gear and Liendo; Verdiglione; Lacan; Rosen; Bär).

In the light of translation theory, Freud's enterprise was a positive and heroic struggle in a communicative commitment, where analysis is interminable and absolute clarity is a dangerous illusion. Thanks to ambiguity, talking is possible, human verbal communication is possible. There was a gargantuan effort spearheaded by the famous John Wilkins in the latter half of the seventeenth century to eliminate ambiguity and create an unambiguous language in which there would be a different word for every conceivable and perceptible entity (Knowlson). Of course this towering gesture of folly came babbling down as it would have been necessary to create an infinite language to be adequate to the infinite variety of human experience. Even repetition is never the same, is never duplicated exactness if for no other reason that each repetition represents an accumulation. So language has a finite number of words to communicate the endless variety of what is humanly lived.

There is a scene in Lewis Carroll's wonderland where Alice explains to the March Hare that to say what you mean and to mean what you say are not the same thing. To this well-known citation it could be added: we are saying much more than we mean, and we are meaning much more than we say. Such 
reflections harmonize with George Steiner's observation that from the dual or subsurface phenomenology of speech

Humboldt derived his well-known axiom: 'All understanding is at the same time a misunderstanding, all agreement in thought and feeling is also a parting of the ways.' Or as Fritz Mauthner put it, it was via language, with its common surface and private base, that men had 'made it impossible to get to know each other' (1975, p. 173).

Freud would be the first to endorse this stance, and a fortiori in the clinical setting: "Every single association, every act of the person under treatment must reckon with the resistance and represents a compromise between the forces that are striving towards recovery and the opposing forces' (S.E., $12: 103$ ). It would be difficult to find a stronger statement: the patient's every single gesture, act, word, is not pure direct expression, but is compromise.

The context of the foregoing communicative impasse serves best to situate a consideration of translation. Roman Jakobson, one of the outstanding figures in the history of linguistics, postulated that there were in effect three kinds of translation. First, intralingual translation or rewording within the same language; in short, paraphrase. Second, interlingual translation or interpretation via another language; this is the most common use of the word. Third, intersemiotic translation or transmutation, that is, the interpretation of verbal signs by means of nonverbal sign systems; nonverbal highway signs are a ready and clear example of this category. The fact is, however, Jakobson's attempt at allembracing categories does not take into account Freud's enormous contribution to the critique of translation.

To follow Freud's understanding of translation or Übersetzung, one should ideally abide or at least recheck with the original texts, whose German term is obscured by such English renderings as "convey" and "transpositions" (cf. S.E. 5: 610 and G.W. 2/3: 615; Origins, p. 120 and Anfängen, p. 130). A survey of the notion of translation in the Freudian corpus reveals its comprehensive scope and its value of giving an imposing coherence to seemingly disparate phenomena. In the most basic sense, more interesting for the lexicographer than for the psychoanalyst, Freud uses the term merely as the equivalent of verbalization either on the literal (S.E. $20: 29)$ or theoretic $(S . E .18: 59)$ level. More importantly, neuroses and symptoms are translations of unconscious material ; and the manifest or pictorial dream is nothing but a kind of internalized intersemiotic translation or transformation of the previous verbal latent dream. The analyst's interpretations are also translations, and even more than this, the very movement of material in the psychic apparatus as such is understood as translation whereas repression is a failure in translation. Freud's literal use of the German Übersetzung as translation and transposition shows us that he conceived as a concomitant unifying activity the translation of ideas and affects into words and the translation or transposition of psychic materials from the unconscious to the conscious levels. Pursuing that insight further, we may note that etymologically the terms translation, metaphor, and transference are synonymous; said otherwise, transference is an unconscious translation and metaphor, or as the early Freud would have it, "a false connection". Since all the 
patient's utterances are proximately or ultimately related to this transference, we may logically conclude that operationally speaking, psychoanalytic treatment is truly a semiotics of approximations, indeed derivations, orbiting around that false connection. Since ambiguous meaning characterizes the analytic patient in his talking and his listening, no wonder Winnicott could say that he never had a patient (counting Guntrip) who could give back exactly what he heard as an interpretation.

It is worthwhile to elaborate some of the ideas in the previous paragraph. Hysterical phantasies can be translated into the motor sphere and portrayed in pantomine (S.E. 9:229); the dreams and hysterical phobias of a certain patient were translations into different languages of a psychic reaction to the same idea (S.E. $4: 259-260)$; screen memories are also to be accounted translations (S.E. 3: 321). Avoiding a word for word or sign for sign equivalence, dreamwork does not preserve the distinctions proper to the original text but rather translates into another script or language (S.E. 15: 172-3), or more accurately, translates into picture writing (S.E. 15: 229); the symbols in dreamwork are "stable translations" (S.E. 15: 151). Although the manifest dream is mostly a translation of latent thoughts into visual frames (S.E. 18:242 and S.E. 20:43-44), yet in order to avoid reductionism it must be remembered that dreams are not just translations of thoughts into archaic form but also represent allocations of libidinal and object cathexes which might be forced into the background during waking life (S.E. 16:457; cf. 18:230). In Letters 46 and 52 to Fliess (cf. also S.E. 23: 96), Freud conceives of the individual as a series of "successive transcripts" representing "the psychical achievement of successive epochs of life. At the frontier between any two such epochs a translation of the psychical material must take place." But a pathological reaction, writes Freud, may interrupt this developmental continuity; that reaction of "failure of translation is what we know clinically as 'repression", (Origins, p. 175; actually "repression", the English equivalent of Verdrängung, is not the best rendition of the term Freud employed here - Versagung, countersaying, denial).

If the patient to some extent can be psychically represented as a vicissitude of translations and here we recall the hysteric suddenly turned obsessional as a bilingual document (S.E. 12:319), so the complementary role of the analyst is that of translator. The analyst interprets or translates dreams $(S . E$. 9:60 and 110) into a rational process (S.E. 22: 220); this includes the present tense of the manifest dream being translated into a wish, into an "I should like" (S.E. 15: 129). The analyst's more general aim is to effect via his translations a translation and transposition of what is unconscious into what is conscious (S.E. 14: 166, 16:435, 23: 159 and 286) and verbally conscious at that, for thinking in pictures is a very incomplete form of becoming conscious. Clearly, although Freud from time to time equates translation and interpretation, translation is a far more reaching concept, however unfortunately eclipsed it may be by the currency of the term interpretation.

Freud's contribution is especially outstanding with respect to Jakobson's third category of inter-medium or intersemiotic translation. While ample attention has been given to the endopsychic semiotics of the rebus used by the 
manifest dream to translate some verbal material of the latent dream ${ }^{1}$, no unifying treatment has ever been accorded to the various externalized and physically expressed translations of verbal material that is a subject throughout Freud's works. In them I have found four different cases where verbality is the final determinant in a physical and externalized translation of the unconscious: I. Generalized hysterical, obsessional and phobic symptomatology. Concerning the "'symbolic' relation between the precipitating cause and the pathological phenomenon" (S.E. 2:5) in hysteria, Freud makes some very shrewd distinctions (S.E. 2: 176, 178-181, 3:34), based on what we may call primary and secondary symbolization. In primary symbolization, an idea gives rise to the sensation : after feeling her grandmother's "piercing" look, Frau Cacilie developed a penetrating pain between her eyes. In secondary symbolization, the sensation gives rise to the idea: among her multiple leg pains, Frau Cacilie selected the one in her right heel, gave it a psychic value, and then complained about not finding herself "on a right footing" with the other patients in the sanatorium. Not only is it sometimes difficult at large to discern whether the idea or the sensation has precedence, but even in the particular instance of primary symbolization there may be actually the restoration of a primary literalism! If this be so, primary symbolization is less often an idiosyncratic expression and more often an indication that hysteria and linguistic practice take their material from a common origin. Hence the slighted hysteric who speaks of being "stabbed in the heart" and who attendantly has precordial sensations may in effect be phenomenologically accurate. Although admittedly problematic, instances of "pure" primary symbolization ${ }^{2}$ are semiotically the more interesting and involve a concrete elaboration which, inter alia, sets them off from the organ speech of schizophrenics (S.E. 14: 198-199). Freud further holds that such an occurrence of concrete primary symbolization in adult life most partly depend for its force and realizability upon an infantile prototype. Thus Dora's dragging her leg, due immediately to having made a "false step" at the lake scene, was based on a childhood incident of having twisted the same foot as she was going downstairs (S.E. $7: 103$ ).

In this realm of intersemiotic symptomatology, care must be taken to distinguish between the gesture-language of hysteria and the thought-language of obsessional neurosis typically manifesting itself in protective measures (S.E. 13: 177-178). Hysterical attacks, moreover, may assume added symbolic complexities in that the patient might take on a multiple identification (the active and the passive partner), exhibit an antagonistic inversion of innervations (the arc de cercle repudiating a copulating posture), and by a sequence of convulsiveness and placidity could reverse the chronological order of seduction $(S . E .9: 230$ 231 and Minutes $1: 371$ ).

1. For hallucinations coming about in the same way, cf. S.E. $2: 181 \mathrm{fn}$.

2. For various examples, see Origins, p. 198 ; Minutes $1: 346$ and $404 ; 2: 80$ and $460-461$; S.E. $10: 128,188-189,213-215 ; 12: 308$, and $18: 187$. I should like to add the example of one of my French-speaking patients who cheated her mate (tromper) and developed a pseudo-infection in her fallopian tubes (les trompes). 
II. Specific choice of a) suicidal means and of b) fetish. For example, a man hangs himself and thereby is pendant like a penis, or a woman by jumping out a window is both falling down and lying in delivery, niederkommt (Minutes, 2: 183 and S.E. 18:162). Then again, there was the patient for whom a "shine on the nose" (Glanz auf die Nase) meant a glance at the nose, whose perceived glow was fetishistically endowed (S.E. 21: 152). III. Intersemiotic parapraxes, which in effect combine elements of the bungling or faulty act and the verbal lapsus. An excellent case of this is one of Ferenczi's reactions to having committed a technical error in treatment: throughout the day he stumbled several times, thereby translating into action his faux pas (S.E. 6: $156 \mathrm{fn}^{3}$ ). This striking adequation between verbal elements and external movement contrasts with its absence in the greater number of parapractic acts. Four possibilities for a richer and intended consideration of intersemiotic parapraxes deserve special mention. First, Silberer's functional phenomenon, whereby the dreamer's mode of functioning is caught redhanded and represented in the dream might obtain in an intersemiotic parapraxis. Thus when Freud awkwardly wrote fïr twice in quick succession and then substituted bis for the second occurrence (S.E. $22: 233-235$ ), the bis and the crossing out of the second fiur are an attempt to undo the mental trace of having given a similar gift to the same party. Secondly, although neither Freud nor, as far as I can ascertain, anyone else in analytical literature has furnished an example of intersemiotic parapraxis based on the opposite, such an entity undoubtedly exists and is in essential accord with the unconscious. In his own private notation (S.E. $6: 49 \mathrm{fn}$.) Freud singled out a dream in which ice symbolized by antithesis an erection; in spite of having no real instance at hand, I can conjure up an intersemiotic parapraxis in which a person mistakenly and "with open arms" bumps into his enemy, thereby cloaking diametrically opposite feelings. I am sure that this new and unpopulated parapractic category could be readily overflowed with incidents hitherto unnoticed. Thirdly, Erikson's programmatic for dream investigation - that it deal with the dreamer's style of representability - might also be valuably applied to the intersemiotic parapraxis. Fourthly, the comparative study has yet to be done of Freud's drawings and diagrams for along with the accompanying commentary they present an intersemiotic manifestation of Freud's psychic operation. In such a venture, care must be taken always to compare even the illustrations in the English version with the original; Erikson (1955, p. 9) caught such an error in the transcription of the Origins. For purposes of revealing Freud's own parapraxis, Strachey should have reproduced the map in $G . W .7: 432$. Freud asks that his structural diagram be mentally rectified by the reader in one place (S.E. 22:79) and in another

3. See also S.E. 6: 48-51, 164-165, 172-173, 177-178, 192, 199-203, 206, and 214. Mention might be made to another one of my patients, a middle-aged woman who in some ways was remarkably dependent and immature; her massive maternal transference onto me was attended by disavowed crises dealing with separation. Several days before I was about to begin my summer vacation, she had gone into a knitting store, which was certainly not her habit, and bought some patch and pattern work to do over the vacation. She was unaware that her choice of object was determined by my first name, so that choosing patch and pattern work was her original way of finding a latter-day transitional object. 
place classifies a similar one as simply heuristic (S.E. 19:24). Fisher (1957) has pointed out the inconsistency between Freud's diagrammatic location of the system Pc. in Chapter Seven of the Interpretation of Dreams and the explanatory prose text.

\section{DISCUSSION}

Backdropped by the traditional puzzlement before the meaning of hysteria, Freud's achievement was truly remarkable, but his achievement merits more wonderment when one refiects on the inherent defiance of language that Freud had to contend with. We know that a translated word most rarely enjoys a congruence of denotation and connotation in the source and target languages and that even within the rare congruence of figurative and literal meanings for the same word, distributions of usage are skewed differently. Neither can we choose to ignore that if denotation and connotation are problematic in interlingual translation, they are likewise in an interlingual setting. Obviously, due to each individual's unique personal history, the meanings he assigns to words are distinctive and all the more so as the form word is more common. Alongside this obstacle, there is the essential distortion of psychic reality, condemned as we are to translate it into the language of perception, a fact Freud twice bemoans ( $S . E .22: 90$ and $23: 196$ ); then again, there is the added obscurity inherent in the figurative language particular to psychological investigation itself $(S . E .18: 60)$.

A brief reference of a linguistic notion enables us to further appreciate Freud's struggle with a lexicality subject to psychic dynamics. Saussure, the father of modern linguistics, conceived of the sign as divided into $\frac{\mathrm{S}}{\mathrm{S}}$, the acoustic image and, roughly, the meaning. In Lacan's reading of the Saussurean sign, the line separating the signifier and the signified is the barrier of repression the result is that language is traumatized, wounded; the signifier cannot be integrally at rest with the signified but instead refers to another signifier in a chain interminable. Contending with and in a lexical heritage of broken signs, Freud's grand solution was one of reintegrating translation, which can be understood in part as a repatriation of the alienated signifiers (see Nicolaidis and Cornu). True enough, Freud's self-analysis, upon which his crucial discoveries in translation depended, had specific indebitudes completely bypassed in Jones' and Schur's biographies: it had as its influential medical counterpart Fliess's autotherapy (autotherapeutischen Versuche, Anfängen, p. 134) and was influenced by the daily chart which Fliess encouraged him to make of his symptoms. These factors notwithstanding, Freud's unifying and centralizing enterprise of translation towers as an extraordinary monument throughout the history of man.

Given Freud's reputed literary style and also his pioneering awareness of the importance of verbal detail, it is surprising that in the beginning he cared little about the poor way in which his works were translated (Jones, 2: 45). 
Perhaps his initial insouciance was motivated by his greater concern that the bulk of his scientific insights be conveyed, and as time went on he paid tribute to the translation of nuance. And yet, as great and fluent as Strachey's translation is, it falters frequently enough in scientific accuracy and more consistently in affective quality (Brandt; Mahony; Brull). As with all great authors, the time will come when Freud will be fully translated anew in English. It is hoped that such a translation, probably taking place in the next century, will be as lexically sensitive as This and Thèves' 45-page translation and commentary on "Negation".

Finally, we lack the kind of history of human consciousness that could serve to better situate Freud's literary style as a blend of personal genius and its deeper interaction with the history of the sensorium and of the communication media. For example, how much would a phenomenological study of psychoanalytical concepts reveal about tactual as opposed to other kinds of sensorial experience (cf. Ong, pp. 92-110)? Different epochs and cultures varied in the authority ascribed to language, in the perceived relations between word and object, in the amount of tacturnity and prolixity and therefore in a redistributed "speech mass", in their inhospitality or openness to new metaphors, in locutory conventions as to how much was concealed or implied or equivocated, and in the ratio between inward and public discourse. Born at a time in European sensibility when techniques of meditation and introspection favoring an inward discourse of analytic argument had shriveled up, psychoanalysis now lives through a period when public verbalization and publicity seem to have greatly reduced internal language (Steiner, 1975 and 1976). In this uncharted area of flux, and semi-assisted, semi-impeded by the treacherous tools of ambiguous language, Freud made his most famous discovery : man and woman are Edipal translators, Edipal traitors. And that is no metaphor.

\section{REFERENCES}

BÄR, E. (1975): Semiotic Approaches to Psychotherapy, Bloomington, Indiana, Indiana University Press.

BRANDT, L. (1961): "Some notes on English Freudian terminology", J. Amer. Psychoanal. Assn., 9, p. 331-339.

BRULL, F. (1975): "A reconsideration of some translations of Sigmund Freud", Psychotherapy: Theory, Research and Practice, 12, p. 273-279.

ERIKSON, E. (1954): "The dream specimen of psychoanalysis", J. Amer. Psychoanal. Assn., 2, p. 5-56.

FISHER, C. (1957): "A study of the preliminary stages of the construction of dreams and images", J. Amer. Psychoanal. Assn., 5, p. 5-6.

FREUD, S. (1893): "On the psychical mechanism of hysterical phenomena", Standard Edition, 2, p. 3-17. London: Hogarth Press, 1955.

(1893-5): "Studies on hysteria", Standard Edition, 2. London: Hogarth Press, 1955. (1899): "Screen memories", Standard Edition, 3, p. 303-322. London: Hogarth Press, 1962 .

(1900): "The interpretation of dreams", Standard Edition, 4 \& 5. London: Hogarth Press, 1953 [Die Traumdeutung. Gesammelte Werke, 2/3. Frankfurt: Fischer, 1973].

(1901a): "The psychopathology of everyday life", Standard Edition, 6. London: Hogarth Press, 1960.

- (1901b): “A case of hysteria", Standard Edition, 7, p. 7-122. London: Hogarth Press, 1953.

(1906): "Psycho-analysis and the establishment of the facts in legal proceedings", Standard Edition, 9, p. 103-114. London : Hogarth Press, 1959.

(1907): "Delusions and dreams in Jenson's Gradiva", Standard Edition, 9, p. 7-95. 
(1909a): "Some general remarks on hysterical attacks", Standard Edition, 9, p. 229-

234. London: Hogarth Press, 1959.

(1909b): "Analysis of a phobia in a five-year boy", Standard Edition, 10, p. 5-149. London: Hogarth Press, 1955.

(1909c) : "Notes upon a case of obsessional neurosis", Standard Edition, 10, p. 155 -

318. [Bemerkungen Über einen Fall von Zwangsneurose. Gesammelte Werke, 7, p. 381-

463. Frankfurt: Fischer, 1972].

(1912): "The dynamics of transference", Standard Edition, 12, p. 99-108. London: Hogarth Press, 1958.

(1913a): "Two lies told by children" Standard Edition, 12, p. 305-309. London: Hogarth Press, 1958.

(1913b): "The claims of psycho-analysis to scientific interest", Standard Edition, 13, p. 165-190. London: Hogarth Press, 1953.

(1915): "The unconscious", Standard Edition, 14, p. 166-204. London: Hogarth Press, 1957.

(1916-1917) : "Introductory lectures on psycho-analysis", Standard Edition, 15 \& 16. London: Hogarth Press, 1963.

(1920a): "Beyond the pleasure principle", Standard Edition, 18, p. 7-64. London: Hogarth Press, 1955.

(1920b): "The psychogenesis of a case of homosexuality in a woman", Standard Edition, 18, p. 147-172. London: Hogarth Press, 1955.

(1923a): "The ego and the id", Standard Edition, 19, p. 12-66. London: Hogarth Press, 1961

(1923b) : "Two encyclopaedia articles", Standard Edition, 18, p. 235-259. London: Hogarth Press, 1955.

(1925a): "Negation", Standard Edition, 19, p. 235-239. London: Hogarth Press, 1961 [Die Verneinung, tr. B. This \& P. Thèves. Le Coq Héron (1975), 52: 1-45].

(1925b): "An autobiographical study", Standard Edition, 20, p. 7-74. London: Hogarth Press, 1959.

(1927): "Fetishism", Standard Edition, 21, p. 152-157. London: Hogarth Press, 1961

(1932): "My contact with Josef Popper-Lynkeus", Standard Edition, 22, p. 219-224. London: Hogarth Press, 1964.

(1933): "New introductory lectures", Standard Edition, 22, p. 7-182. London: Hogarth Press, 1964.

(1935): "The subtleties of a faulty action", Standard Edition, 22, p. 233-235. London: Hogarth Press, 1964.

(1939): "Moses and monotheism: three essays", Standard Edition, 23, p. 7-137. London: Hogarth Press, 1964.

(1940a): "An outline of psycho-analysis", Standard Edition, 23, p. 144-207. London: Hogarth Press, 1964.

(1940b): "Some elementary lessons in psycho-analysis", Standard Edition, 23, p. 281286. London: Hogarth Press, 1964.

(1941): "Psycho-analysis and telepathy", Standard Edition, 18, p. 177-193. London: Hogarth Press, 1955.

- (1950): "The Origins of Psycho-Analysis", New York: Basic Books, 1954 [Aus den Anfängen der Psychoanalyse. London: Imago Books, 1950].

GEAR, C. \& LIENDO, E. (1975) : Sémiologie psychanalytique, tr. D. Glauser \& M. Tulien. Paris, Éditions de Minuit.

JAKOBSON, R. (1971): "On linguistic aspects of translation", In Selected Writings, 2, p. 260-266, The Hague: Mouton.

JONES, E. (1953-1957): The Life and Works of Sigmund Freud, 3 Vols., New York, Basic Books.

KNOWLSON, J. (1975): Universal Language Schemes in England and France: 1600-1800, Toronto, University of Toronto Press.

LACAN, J. (1966) : Écrits, Paris, Éditions du Seuil.

LIBERMAN, D. (1970): Lingüistica, interraccion, communicativa v proceso psicoanalitica, Buenos Aires : Editorial Galerna.

MAHONY, P. (1977): "Towards a formalist approach to dreams", Internat. Rev. PsychoAnàl. . 4, p. 83-98

NICOLAÏDIS, N. \& CORNU, F. (1976): «Étude du signifiant psychoanalytique à travers les «Cinq Psychanalyses» de S. Freud», Rev. fr. Psychan., 40, p. 325-350. 
NUNBERG, H. \& FEDERN, E. eds. (1906-1915): Minutes of the Vienna Psychoonalytic Society ( 4 vols.), New York, International Universities Press.

ONG, W. (1967): The Presence of the Word, New Haven, Yale University Press.

ROSEN, V. (1970): "Sign phenomena and their relationship to unconscious meaning", Internat. J. Psycho-Anal, , 50, p. 197-207.

SCHUR, M. (1972): Freud: Living and Dying, New York, International Universities Press. STEINER, G. (1975): After Babel: Aspects of Translation and Language, London, Oxford University Press.

(1976): "A note on language and psychoanalysis", Internat. Rev. Psycho-Anal., 3, p. 253-258

VERDIGLIONE, A., ed. (1975): Psychanalyse et sémiotique, Paris, Union Générale d'Éditions. 